\section{Educación y educación física: presencia curricular de la educación física en el sistema educativo español; verificación y análisis de la condición física de los alumnos que inician sus estudios en el institut Torredembarra}

UTE. Revista de Ciències de l'Educació

2016 núm. 2. Pag. 91

ISSN 1135-1438. EISSN 2385-4731

http://revistes.publicacionsurv.cat/index.php/ute

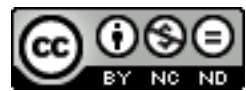

DOI: http://dx.doi.org/10.17345/ute.2016.2.1006

\author{
Pablo Arbós Arquéa \\ Data de defensa: 10/02/2016
}

Paraules clau: Educació/Educació física; Desenvolupament Curricular; Condició física/Bateria Eurofit; Educación / Educación física; Desarrollo curricular; Condición física/Bat. Eurofit; Education/Physical Educat.; Curriculum development; Physical condiction/Eurofit

\title{
Resum
}

L'Educació i l'Educació física, es troben en el denominador comú de la tesi "Educació i Educació Física: presència curricular de l'educació física en el sistema educatiu espanyol; verificació i anàlisi de la "condició física" dels alumnes que inicien els seus estudis a l'Institut Torredembarra".El difícil camí recorregut por la disciplina per a ser considerada de forma legal i explícita en els Plans d'estudi de l'Estat espanyol és un dels aspectes indagats. Relacionades de manera sincrònica les fites superades, la investigació s'orienta envers dos objectius: I'anàlisi curricular de l'Educació física "activat/aplicat" en cada moment històric i, "l'estudi/anàlisi" de les lleis fonamentals i Orgàniques que guien i condueixen el "quefer" professional per mandat imperatiu. L'estudi situa dos marcs físics i acadèmics. La universitat U.R.V., on s'implementa tota la fonamentació teòrica i I'Institut Torredembarra, facilitador de l'alumnat que inicia els seus estudis a l'esmentat institut. En conjunt, la tesi desenvolupa el seu contingut amb dues idees preconcebudes. D'una banda, seguint les lleis educatives, s'aprofundeix en el coneixement de les vicissituds de l'Educació física, i d'altra banda, des de la legalitat vigent, s'instrumenta una investigació per verificar els efectes observables en l'alumnat que accedeix de l'educació primària a l' educació secundària. Per a esbrinar la "condició física" s'apliquen els tests de la Bateria Eurofit que, tractats estadísticament, mostren resultats que haurien de tenir-se en compte al moment de programar la intervenció educativa des de l'Educació física per a l'Educació Secundària.

\footnotetext{
a Universitat Rovira i Virgili
} 